\title{
Responses of late-lactation cows to forage substitutes in low-forage diets supplemented with by-products ${ }^{1}$
}

\author{
M. B. Hall*2 and L. E. Chase† \\ *US Dairy Forage Research Center, USDA Agricultural Research Service (ARS), Madison, WI 53706 \\ †Department of Animal Science, Cornell University, Ithaca, NY 14853
}

\begin{abstract}
In response to drought-induced forage shortages along with increased corn and soy prices, this study was conducted to evaluate lactation responses of dairy cows to lower-forage diets supplemented with forage substitutes. By-product feeds were used to completely replace corn grain and soybean feeds. Forty-eight latelactation cows were assigned to 1 of 4 diets using a randomized complete block design with a 2 -wk covariate period followed by a 4-wk experimental period. The covariate diet contained corn grain, soybean meal, and $61 \%$ forage. Experimental diets contained chopped wheat straw (WS)/sugar beet pulp at $0 / 12,3 / 9,6 / 6$, or $9 / 3$ percentages of diet dry matter $(\mathrm{DM})$. Corn silage (20\%), alfalfa silage (20\%), pelleted corn gluten feed (25.5\%), distillers grains (8\%), whole cottonseed (5\%), cane molasses/whey blend (7\%), and vitamin and mineral mix with monensin (2.5\%) comprised the rest of diet DM. The WS/sugar beet pulp diets averaged $16.5 \%$ crude protein, 35\% neutral detergent fiber, and $11 \%$ starch (DM basis). Cows consuming the experimental diets maintained a $3.5 \%$ fat- and protein-corrected milk production $(35.2 \mathrm{~kg}$; standard deviation $=5.6 \mathrm{~kg})$ that was numerically similar to that measured in the covariate period $(35.3 \mathrm{~kg}$; standard deviation $=5.0 \mathrm{~kg})$. Intakes of DM and crude protein declined linearly as WS increased, whereas neutral detergent fiber intake increased linearly. Linear increases in time spent ruminating (from 409 to $502 \mathrm{~min} / \mathrm{d}$ ) and eating (from 156 to $223 \mathrm{~min} / \mathrm{d}$ ) were noted as WS inclusion increased. Yields of milk fat and $3.5 \%$ fat-and protein-corrected milk did not change as WS increased, but those of protein and lactose declined linearly. Phosphorous intakes were in excess of recommended levels and decreased linearly with increasing WS inclusion. Nutritional model
\end{abstract}

\footnotetext{
Received September 29, 2013.

Accepted January 26, 2014.

${ }^{1}$ Mention of any trademark or proprietary product in this paper does not constitute a guarantee or warranty of the product by the USDA or the Agricultural Research Service and does not imply its approval to the exclusion of other products that also may be suitable.

${ }^{2}$ Corresponding author: marybeth.hall@ars.usda.gov
}

predictions for multiparous cows were closest to actual performance for the National Research Council 2001 model when a metabolizable protein basis was used; primiparous cow performance was better predicted by energy-based predictions made with the National Research Council or Cornell Net Carbohydrate and Protein System models. Model predictions of performance showed a quadratic diet effect with increasing WS. Lactating dairy cows maintained production on low-forage diets that included forage substitutes, and in which by-product feeds fully replaced corn grain and soybean. However, longer-term studies are needed to evaluate animal performance and to improve model predictions of performance on these nontraditional diets.

Key words: by-product, dairy cow, forage substitute, milk production, diet formulation

\section{INTRODUCTION}

In order for dairy farms to remain viable through diverse weather and market conditions that affect forage production and feed prices, dairy farmers and dairy nutritionists need more information regarding acceptable diet formulation strategies. Specifically, information is needed regarding what alternatives to forages, corn, and soybean meal can be used to formulate diets that maintain animal health and performance. The drought and elevated temperatures that affected the United States in 2012 generated the "worst agricultural calamity since 1988" in that country, reducing both forage availability and grain production (USDA, 2013a). Dairies without adequate forage were recommended to feed alternatives such as wheat straw and sugar beet pulp (S. J. Rymph, Purina Animal Nutrition LLC, Mazomanie, WI, personal communication). Feed prices reached historic highs for both corn grain $(\$ 570 / \mathrm{t})$ and high-protein soybean meal $(\$ 1,026 / \mathrm{t})$ in 2012 to $2013\left(\mathrm{t}=10^{3} \mathrm{~kg}\right.$; USDA, 2013b). In this same time frame, by-product feeds from the processing of corn grain by the bioenergy or corn-milling industries were abundant, and had competitive prices per kilogram of $\mathrm{CP}$ and TDN (corn gluten feed: $\$ 0.96$ and $\$ 0.31$; distillers dried grains: $\$ 1.14$ and $\$ 0.38$ ) compared with corn 
grain ( $\$ 3.56$ and $\$ 0.37$ ) and high-protein soybean meal ( $\$ 1.07$ and $\$ 0.71$; prices from USDA, 2013b). Dairy farms increased substitution of by-products for corn and soybean meal as a means to reduce diet costs. In comparison to corn grain, corn-derived by-product feeds have reduced starch contents and so their substitution for corn grain will reduce the amount of supplemented starch in diets.

A challenge in formulating diets to combine use of forage alternatives with complete substitution of byproduct feeds for corn and soy is that studies in the literature do not address this scenario. Published research and reviews have addressed various aspects that relate, such as use of fibrous by-products with high- or lowNDF and forage diets (Pereira et al. 1999), replacement of forages with nonforage fiber (Clark and Armentano, 1997), physical effectiveness of by-products compared with forage (Mooney and Allen, 1997), physically effective fiber requirements relative to acid production in the rumen (Allen, 1997), and replacing forage with forage substitutes (Boguhn et al., 2010). Those studies give insights regarding how cows may respond to dietary changes that affect forage and concentrate supplementation, but do not provide information on how they respond to both simultaneously.

The objective of the present study was to evaluate the performance of lactating dairy cows offered different combinations of forage substitutes in diets that were relatively low in forage and supplemented solely with by-products using no supplementary sources of corn grain or soybean meal. For the forage substitutes used, wheat straw was selected as a source of effective fiber, and sugar beet pulp as a source of more fermentable fiber. Many different permutations of by-product feed choices exist that could be tested in such a study. We chose to use corn gluten feed as the main supplement as well as dried distillers grains, whole cottonseed, and molasses, as these particular feedstuffs were readily available and competitively priced at the time of the study. Additionally, the results of the feeding study were used to evaluate the accuracy with which $2 \mathrm{nu}-$ tritional models predicted cow performance and DMI.

\section{MATERIALS AND METHODS}

Forty-eight late-lactation Holstein cows, including 8 that were ruminally cannulated were included in a randomized complete block design with a covariate feeding period. Cows averaged $1.3 \pm 0.6$ lactations, $32.4 \pm 4.9$ $\mathrm{kg}$ of milk/d, $648 \pm 86 \mathrm{~kg}$ of BW, and $280 \pm 79 \mathrm{DIM}$ at the start of the trial. Twelve multiparous and 35 primiparous cows were used. Within parity (parity = 1 or $>1$ ) and production level, cows were randomly assigned to treatments. Cows were offered a high-forage
TMR (covariate diet) in the first 2 wk of the study and then offered 1 of 4 experimental diets for 4 wk. Diets were offered once daily at $0700 \mathrm{~h}$. The experimental diets contained only $40 \%$ true forage (corn and alfalfa silages), and differed in the amount of the forage substitutes chopped wheat straw (WS) or sugar beet pulp pellets (SBP) they contained, ranging from $0 \%$ $\mathrm{WS}+12 \%$ SBP to $9 \% \mathrm{WS}+3 \%$ SBP (DM basis; Table 1). All other ingredients were kept in the same proportions in all diets. No supplemental corn grain or soybean products were included in the experimental diets. Molasses was included for its feeding value and to bind the diets together and reduce sorting. Diets met NRC (2001) requirements for all nutrients except energy based on profiles and DMI of animals in the covariate period. We did not formulate for energy in part because we questioned whether the calculated energy estimates would be correct given the unusual formulations of the diets compared with diets used to develop the dairy NRC (2001) requirements. Diets formulated without additional sugar or fat sources would allow evaluation of whether cows could meet energy requirements through increased intake of diets that were calculated to contain lesser concentrations of energy than the covariate diet. The diets contained monensin. Animals were maintained under protocols approved by the University of Wisconsin Institutional Animal Care and Use Committee (Madison).

Collection of samples and animal response data was performed in wk 2 of the covariate period and in wk 4 of the experimental feeding period. Milk weights were recorded for all milkings during collection periods and samples collected from all milkings on d 5 through 7 of collection weeks. Milk samples were analyzed for composition by infrared analysis using a Foss FT6000 instrument (method 972.16; AOAC International, 1996; Foss Electric A/S, Hillerød, Denmark; analyses performed by AgSource Milk Analysis Laboratory, Menomonie, WI). Production of $3.5 \%$ fat- and protein-corrected milk (FPCM) was calculated as (derived from Tyrrell and Reid, 1965) follows: $3.5 \%$ FPCM kg/d $=[12.82 \times$ fat $(\mathrm{kg} / \mathrm{d})]+[7.13 \times$ protein $(\mathrm{kg} / \mathrm{d})]+[0.323 \times$ milk $(\mathrm{kg} / \mathrm{d})]$. Feed efficiency was calculated as $3.5 \%$ FPCM divided by DMI. Efficiency of dietary $\mathrm{N}$ utilization was calculated as ( $\mathrm{kg}$ of milk protein/6.38)/( $\mathrm{kg}$ of DMI $\times$ dietary $\mathrm{CP} \% / 6.25)$. Body weights were measured after morning milking on 2 consecutive days in the covariate and experimental sampling weeks. Body weight change was calculated for each cow as the difference in mean BW measured during the covariate and experimental period sampling weeks.

Fecal and ruminal $\mathrm{pH}$ were measured on d 6 of collection weeks using an electronic pH meter (315i; WTW Wissenschaftlich-Technische Werkstätten GmbH, Wei- 
Table 1. Feed and chemical compositions of study diets

\begin{tabular}{|c|c|c|c|c|c|}
\hline \multirow[b]{2}{*}{ Diet composition } & \multirow{2}{*}{$\begin{array}{c}\text { Covariate } \\
\text { diet }\end{array}$} & \multicolumn{4}{|c|}{$\mathrm{WS} / \mathrm{SBP},{ }^{1} \%$ of $\operatorname{diet} \mathrm{DM}$} \\
\hline & & $0 / 12$ & $3 / 9$ & $6 / 6$ & $9 / 3$ \\
\hline \multicolumn{6}{|l|}{ Ingredient, $\%$ of DM } \\
\hline Corn silage & 28.6 & 20 & 20 & 20 & 20 \\
\hline Alfalfa silage & 32.4 & 20 & 20 & 20 & 20 \\
\hline Chopped wheat straw & - & 0 & 3 & 6 & 9 \\
\hline Sugar beet pulp & - & 12 & 9 & 6 & 3 \\
\hline Distillers grains & 4.0 & 8 & 8 & 8 & 8 \\
\hline Corn gluten feed & - & 25.5 & 25.5 & 25.5 & 25.5 \\
\hline Whole cottonseed & - & 5 & 5 & 5 & 5 \\
\hline Vitamin and mineral mix & 2.4 & 2.5 & 2.5 & 2.5 & 2.5 \\
\hline Molasses 80:20 cane:whey & - & 7 & 7 & 7 & 7 \\
\hline High-moisture corn & 20.7 & - & - & - & - \\
\hline Roasted soybeans & 7.9 & - & - & - & - \\
\hline High-protein soybean meal & 3.7 & - & - & - & - \\
\hline Sodium bicarbonate & 0.25 & - & - & - & - \\
\hline Salt & 0.13 & - & - & - & - \\
\hline Diet DM, \% & 45.8 & 52.6 & 54.8 & 53.8 & 54.0 \\
\hline \multicolumn{6}{|c|}{ Chemical composition, $\%$ of diet DM } \\
\hline $\mathrm{CP}$ & 16.6 & 16.8 & 16.6 & 16.3 & 16.1 \\
\hline $\mathrm{aNDF}^{2}$ & 28.8 & 32.8 & 34.1 & 35.4 & 36.7 \\
\hline Starch & 24.8 & 11.3 & 11.3 & 11.3 & 11.3 \\
\hline $\mathrm{NFC}$ & 42.4 & 35.0 & 33.8 & 32.7 & 31.5 \\
\hline $\mathrm{Ca}$ & 0.96 & 1.01 & 0.98 & 0.95 & 0.92 \\
\hline $\mathrm{P}$ & 0.36 & 0.54 & 0.54 & 0.54 & 0.54 \\
\hline $\mathrm{K}$ & 1.67 & 1.69 & 1.72 & 1.75 & 1.78 \\
\hline $\mathrm{Mg}$ & 0.37 & 0.45 & 0.45 & 0.44 & 0.44 \\
\hline $\mathrm{S}$ & 0.20 & 0.34 & 0.33 & 0.33 & 0.32 \\
\hline Forage $^{3} \%$ of DM & 61 & 40 & 43 & 46 & 49 \\
\hline $\mathrm{NE}_{\mathrm{L}},{ }^{4} \mathrm{Mcal} / \mathrm{kg}$ & 1.70 & 1.64 & 1.62 & 1.61 & 1.59 \\
\hline Forage aNDF/diet aNDF, $\%$ & 81 & 46 & 52 & 57 & 62 \\
\hline
\end{tabular}

${ }^{1} \mathrm{WS}=$ chopped wheat straw; $\mathrm{SBP}=$ sugar beet pulp pellets.

${ }^{2}$ aNDF $=$ amylase- and sodium sulfite-treated NDF.

${ }^{3}$ Corn silage, alfalfa silage, and chopped wheat straw are included in forage.

${ }^{4} \mathrm{The}_{\mathrm{NE}}$ values of diets were calculated from values for individual feeds, which were determined using NRC (2001) equations.

lheim, Germany). Fresh fecal samples were obtained from all cows between 0745 and $0830 \mathrm{~h}$. The $\mathrm{pH}$ was measured by directly inserting the probe of the $\mathrm{pH}$ meter into the undiluted samples. Rumen $\mathrm{pH}$ of cannulated cows was measured just before feeding and $4 \mathrm{~h}$ postfeeding. Rumen fluid samples were obtained manually from the ventral portion of the rumen, transferred to $500-\mathrm{mL}$ containers, sealed, inverted to mix, and the $\mathrm{pH}$ read immediately.

Cow behaviors of eating and ruminating were recorded on d 3 and 4 of each collection week. Behaviors were recorded every $10 \mathrm{~min}$ for $24 \mathrm{~h}$ by dedicated observers in the barn except when cows were away from their stalls for milking. The behavior taking place at the start of each 10-min interval was recorded and calculated as extending for the entire 10-min interval.

One ruminally cannulated cow was omitted from all analyses except for ruminal $\mathrm{pH}$. This cow had very low milk production, but her DMI was in the range of other animals retained in the study (performance of excluded cow: 10.3 and $5.6 \mathrm{~kg}$ of $3.5 \%$ FPCM and 22.6 and 26.4 $\mathrm{kg}$ of DMI, in the covariate and experimental periods, respectively). The percentage DMI per BW for this animal was $0.5 \%$ less than the next lowest cow in both the covariate and experimental periods.

\section{Sample Collection and Analysis}

The amounts of diets fed and refused were recorded daily for each cow during the 7-d collection weeks. Samples of silages and wheat straw were obtained daily through the collection phases and composited. All nonforage supplements were sampled once during the sampling weeks. All samples were frozen at $-20^{\circ} \mathrm{C}$ until analysis. Duplicate subsamples of composited and individual feeds were dried in forced-air ovens at $55^{\circ} \mathrm{C}$. One subsample for each feed dried at $55^{\circ} \mathrm{C}$ was subsequently dried at $105^{\circ} \mathrm{C}$ for $48 \mathrm{~h}$ to determine DM. Samples dried at $105^{\circ} \mathrm{C}$ were also used for particle size determination. The individual feeds dried at $55^{\circ} \mathrm{C}$ for $24 \mathrm{~h}$ and used for compositional analysis were ground to pass the 1-mm screen of a Wiley mill (Arthur H. Thomas Co., 
Philadelphia, PA). Daily DMI was calculated for each animal as the difference on a $105^{\circ} \mathrm{C} \mathrm{DM}$ basis between weights of feed offered and orts collected. The chemical compositions and energy contents of TMR (Table 1) were calculated based on the proportions of feeds in the diets and chemical analyses of individual feeds.

Nitrogen content of samples was analyzed by combustion analysis (AOAC International, 1996; method 990.03) and converted to a CP basis by multiplication by 6.25 . Neutral detergent fiber was measured using $\mathrm{Na}_{2} \mathrm{SO}_{3}$ and heat-stable $\alpha$-amylase (Mertens, 2002) and expressed inclusive of residual ash. The AOAC International (1996) method 973.18 was used to determine sulfuric acid lignin content and to produce ADF residue for determination of $\mathrm{CP}$ content in ADF. Both NDF residue generated without the use of $\mathrm{Na}_{2} \mathrm{SO}_{3}$ and $\mathrm{ADF}$ residue were analyzed for nitrogen content by the combustion method (AOAC International, 1996; method 990.03). Digestibility of NDF was determined according to the method of Goering and Van Soest (1970) using inoculum preparation and NDF residue analysis as described by Hall and Mertens (2008). Starch was analyzed according to the sodium acetate buffer method described by Hall (2009). Ash was analyzed by AOAC International (1996) method 942.05. Minerals in feeds were analyzed by using a microwave and furnace dry ash digestions and inductively coupled plasma spectroscopy according to AOAC International (1996; method 985.01). Energy $\left(\mathrm{NE}_{\mathrm{L}}\right)$ values for individual feeds were calculated from their composition (NRC, 2001).

Sets of US standard testing sieves (Fisher Scientific Co., Pittsburg, PA) were used to determine particle size, with forages, SBP, and pelleted corn gluten feed analyzed using $13.2-\mathrm{mm}, 9.5-\mathrm{mm}, 6.7-\mathrm{mm}$, and no. 4, 6, $8,12,16,20,30$, and 50 sieves, and WS analyzed using 6.7-mm and no.4, 6, 8, 12, 16, 20, 30, and 50 sieves. Dried feed samples were shaken through the screens for 10 min using a Ro-Tap test sieve shaker (W. S. Tyler Industrial Group, Mentor, $\mathrm{OH}$ ). Results were used to calculate geometric mean particle size (ANSI/ASAE, 1992).

\section{Model Evaluations}

Each of the 4 experimental diets was evaluated with the NRC (2001) and Cornell Net Carbohydrate and Protein System 6.1 (CNCPS; version 52; Cornell University, Ithaca, NY) 52 models to estimate predicted performance and DMI. Predictions for first-lactation and multiple-lactation cows were made in separate model runs for each diet. Information on composition of individual feedstuffs, inclusion levels of feedstuffs in the diets, and average animal BW and actual DMI for each treatment and class of cattle was used. Model li- brary values for feed nutrients (e.g., AA) and digestion rates were used when no direct analytical data were available.

\section{Feed Costs and Milk Income}

Feed costs and milk income for each of the experimental diets were calculated. Proportions of feeds in diets, and average DMI, milk production, and milk composition for cows on each experimental diet were used. As-fed feed prices per metric tonne (rounded to the nearest US dollar) used were as follows: corn silage: $\$ 132$; alfalfa silage: $\$ 187$; chopped wheat straw: $\$ 254$; distillers grains with solubles: $\$ 633$; sugar beet pulp: $\$ 646$; corn gluten feed: $\$ 540$; whole cottonseed: $\$ 791$; molasses 80:20 cane:whey blend: $\$ 650$; high-moisture shell corn: $\$ 445$; roasted soy: $\$ 1,168$; high-protein soybean meal: $\$ 1,085$; vitamin and mineral mix: $\$ 1,984$; salt: $\$ 216$; and sodium bicarbonate: $\$ 694$. Milk prices per hundredweight were calculated using milk fat and protein percentages from each treatment and Midwest area prices as calculated with an online milk valuation program (Adisseo, 2012). Milk prices per hundredweight were divided by 45.36 to convert them to a per kilogram basis.

\section{Statistical Analysis}

Variables used in the statistical analyses were $\mathrm{Y}=$ the dependent variable, $\mu=$ overall mean, $\mathrm{C}_{\mathrm{i}}=$ cannulated cow $(\mathrm{i}=1 \ldots 8), \mathrm{D}_{\mathrm{j}}=\operatorname{diet} \mathrm{WS}$ content $(\mathrm{j}$ $=0,3,6$, and $9 \%), \operatorname{Cov}_{\mathrm{k}}(\mathrm{k}=$ value for the dependent variable determined in the covariate period), $\mathrm{H}_{1}$ ( 1 = hour of rumen sampling $), \mathrm{M}_{\mathrm{m}}(\mathrm{m}=$ nutritional model-nutrient basis as NRC-NE $\mathrm{L}_{\mathrm{L}}$, NRC-MP, CNCPS$\mathrm{ME}$, and CNCPS-MP), and $\varepsilon=$ residual error. In the statistical models, interaction terms were represented by combinations of the letters used to represent variables. Terms including "cow" were treated as random variables.

Average daily values per cow per sampling week for milk production, milk composition, DMI, feed fraction intake, feed efficiencies, and BW change and behavior measurements were analyzed with the model $Y_{j k}=\mu+$ $D_{j}+\operatorname{Cov}_{k}+\varepsilon_{j k}$. In these analyses, diet was treated as a classification variable. Ruminal time course data from the 0 - and 4-h samplings were analyzed as repeated measures in time with the model $\mathrm{Y}_{\mathrm{ijk}}=\mu+\mathrm{C}_{\mathrm{i}}\left(\mathrm{D}_{\mathrm{j}}\right)+$ $\mathrm{D}_{\mathrm{j}}+\mathrm{H}_{\mathrm{l}}+\mathrm{D}_{\mathrm{j}} \mathrm{H}_{\mathrm{l}}+\operatorname{Cov}_{\mathrm{k}}+\varepsilon_{\mathrm{ijkl}}$. The covariance structure was selected on the basis of which structure gave the smallest corrected Akaike information criterion value. Linear or quadratic responses over the 4 experimental dietary treatments were evaluated with contrasts. A single nonorthogonal contrast evaluating $0 \% \mathrm{WS}$ versus 
3,6 , and $9 \%$ WS was performed for the ruminal $\mathrm{pH}$ data. Comparisons of actual performance versus nutritional model predictions for milk production and DMI were performed with the model $\mathrm{Y}_{\mathrm{jm}}=\mu+\mathrm{D}_{\mathrm{j}}+\mathrm{M}_{\mathrm{m}}+$ $D_{j} M_{m}+D_{j} D_{j}+D_{j} D_{j} M_{m}+\varepsilon_{j m}$. For evaluation of diet costs and milk income the model used was $Y_{j}=\mu+D_{j}$ $+\mathrm{D}_{\mathrm{j}} \mathrm{D}_{\mathrm{j}}+\varepsilon_{\mathrm{j}}$. In statistical models for model evaluation and economic data, Diet was treated as a continuous variable. Terms were removed from the model if $P>$ 0.25 , with interaction terms removed before lower-order terms that contained the same variables. If the nutritional model term had $P<0.05$, mean separation was performed using the Tukey-Kramer test (SAS Institute, 2010).

With the exclusion of the 1 low-producing cow from all but rumen $\mathrm{pH}$ evaluation, all other statistical evaluations used data from 3 multiparous cows and 9 primiparous cows on each treatment, except for the $0 \%$ WS $+12 \%$ SBP diet, which used 8 primiparous and 3 multiparous animals. Except where indicated, results are reported as least squares means with standard error of the difference (SED). Significance was declared at $P<0.05$ and tendency at $0.05 \leq P \leq 0.10$. Analyses were performed with PROC MIXED of SAS (version 9.3; SAS Institute, 2010).

\section{RESULTS AND DISCUSSION}

The forages and forage substitutes had differing compositions that altered overall diet characteristics (Table 2 ). Among the forages (corn silage and alfalfa silage) and forage substitutes (WS and SBP), numerically, alfalfa silage had the greatest $\mathrm{CP}$ content and corn silage had the greatest starch content. Sugar beet pulp pellets were numerically comparable to alfalfa and corn silages in NDF content, whereas NDF content of WS was approximately twice as great as for the other 3 feeds. This characteristic led to increasing NDF content of the experimental diets as WS inclusion increased (Table 1 ). Wheat straw also had the numerically lowest $\mathrm{CP}$ and NFC contents; increasing WS and decreasing SBP gave numeric declines in both $\mathrm{CP}$ and $\mathrm{NFC}$ content. Although SBP had the numerically greatest mean particle size, this value likely does not represent the actual particle size of SBP in the rumen. Intact pellets measured $7 \mathrm{~mm}$ in cross-sectional diameter and varied in length, but were composed of finer particles compressed into pellets. Individual particles resulting from dissolution of the pellet in the rumen would give a finer particle size than the original pellet. The very narrow range of particle sizes for SBP speaks to the physical uniformity of this manufactured product. The comments regarding SBP also apply to the corn gluten feed pellets, which were $6 \mathrm{~mm}$ in cross-sectional diameter.
Across experimental diets, starch remained consistently at $11.3 \%$ of DM, which was slightly less than half the starch content found in the conventional covariate diet. Phosphorous contents of the experimental diets were 1.5 times the concentrations found in the covariate diet because the by-product feeds had greater $\mathrm{P}$ contents than the forages or grains they replaced. No benefits have been shown for providing lactating dairy cows with dietary concentrations of $\mathrm{P}$ greater than $0.42 \%$ of DMI (NRC, 2001).

\section{Behavioral Responses and $\mathrm{pH}$}

Ruminal responses to the varying proportions of WS and SBP appear to relate, at least in part, to their different physical forms. Time spent ruminating and eating increased linearly with increasing inclusion of WS $(P<0.01$ for both; Figure 1). Increases in both time spent eating and ruminating have also been reported with alfalfa silage as particle size increased (Krause et al., 2002).

Despite differences in rumination time, ruminal $\mathrm{pH}$ was not affected by diet $(P=0.21)$, sampling hour $(P$ $=0.62)$, or diet-by-hour interaction $(P=0.71$; Figure 2 ). The rumen $\mathrm{pH}$ of cows on the $0 \% \mathrm{WS}+12 \% \mathrm{SBP}$ diet tended to be lower than that of the other experimental treatments $(P=0.07)$. Unexpectedly, no difference was detected in ruminal $\mathrm{pH}$ between 0 - and 4-h measurements postfeeding. On diets containing greater amounts of starch, ruminal $\mathrm{pH}$ declines postfeeding as fermentable substrates enter the rumen and their fer-

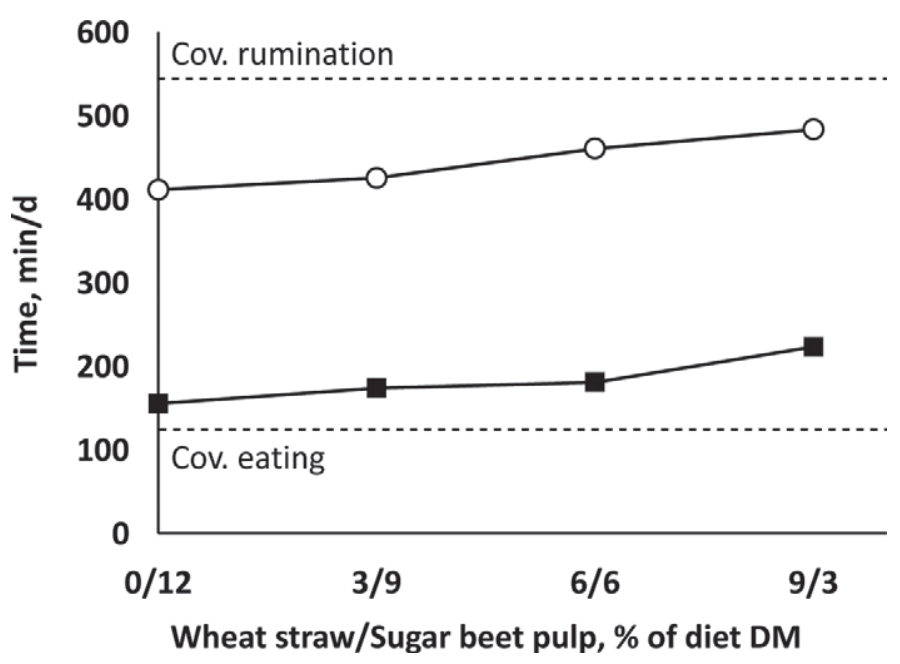

Figure 1. Time spent ruminating or eating as affected by dietary treatment. $\bigcirc=$ rumination; $\boldsymbol{\square}=$ eating (LSM). Dashed lines are the average minutes per day for eating and ruminating observed in the covariate (Cov.) period. Both time spent ruminating $[P<0.01 ; \mathrm{SE}$ of the difference $(\mathrm{SED})=21.6]$ and eating $(P<0.01 ; \mathrm{SED}=20.1)$ increased linearly as dietary wheat straw inclusion increased and that of sugar beet pulp decreased. 


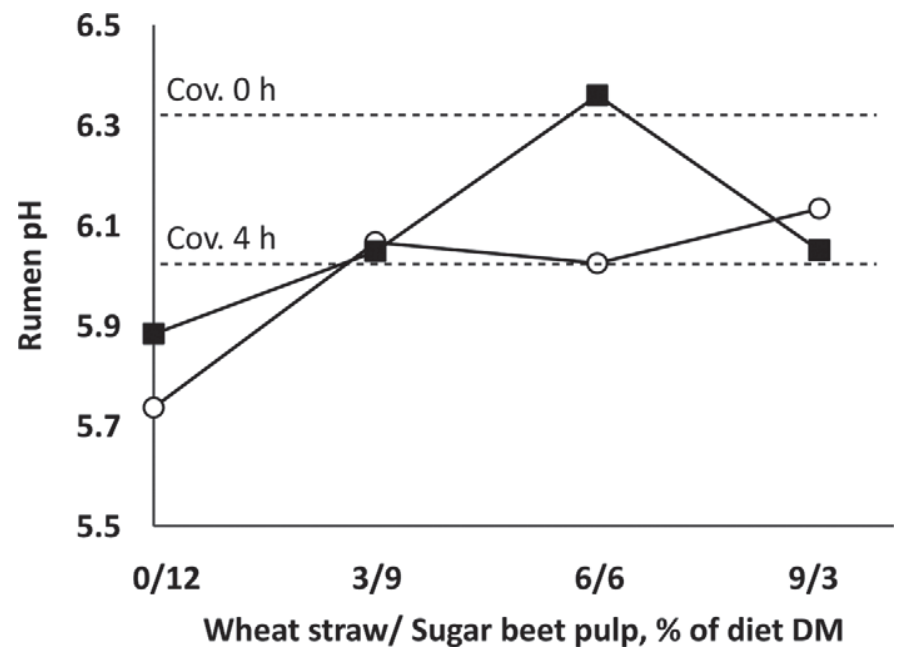

Figure 2. Ruminal $\mathrm{pH}$ at 0 and $4 \mathrm{~h}$ postfeeding as affected by dietary treatment. $\mathrm{O}=0$-h $\mathrm{pH} ; \boldsymbol{\square}=4$-h $\mathrm{pH}$ (LSM). Dashed lines are the average $\mathrm{pH}$ at 0 and $4 \mathrm{~h}$ postfeeding observed in the covariate (Cov.) period. Ruminal $\mathrm{pH}$ was unaffected by diet, time of sampling, or the interaction of these variables $[P>0.20$ for all; SE of the difference $(\mathrm{SED})=0.25]$. A tendency existed for cows receiving the $0 \%$ wheat straw $+12 \%$ sugar beet pulp diet to have a lower $\mathrm{pH}$ than cows on the other $\operatorname{diets}(P=0.07)$.

mentation commences (e.g., Hall et al., 2010). Results of the present study suggest that less OM was being fermented in the early hours postfeeding than is seen on more conventional lactating cow diets containing more forage, soybean meal, and corn grain. A major determinant of ruminal $\mathrm{pH}$ is the balance between acid production from the fermentation of OM and the secretion of buffer through saliva (Allen, 1997). Saliva flow increases with rumination (Bailey and Balch, 1961). The increased rumination as WS increased in the present study could have increased buffering from saliva, but no increase was detected in ruminal $\mathrm{pH}$ after the first substitution of 3\% WS for SBP. Increases in liquid delivery to the rumen could also increase liquid outflow, which could also reduce VFA concentrations and increase ruminal $\mathrm{pH}$. Ruminal acid production or liquid flow data are needed to definitively evaluate the degrees to which rumination or VFA production affected ruminal $\mathrm{pH}$ in the present study. Fecal $\mathrm{pH}$ was not affected by treatment $(6.39,6.51,6.43$, and 6.49 for $0,3,6$, and $9 \%$ WS diets, respectively; effects of diet: linear $P=$ 0.32 , quadratic $P=0.48 ; \mathrm{SED}=0.065)$. Differences in fecal $\mathrm{pH}$ could be interpreted as qualitatively indicating differences in the amount of hindgut fermentation. In the present study, lack of differences among treatments could reflect similar degrees of hindgut fermentation.

\section{Intake and Performance}

Changes in the proportions of forage substitutes altered DMI and intake of various dietary fractions. Dry

Table 2. Composition of forages, forage substitutes, and corn gluten feed

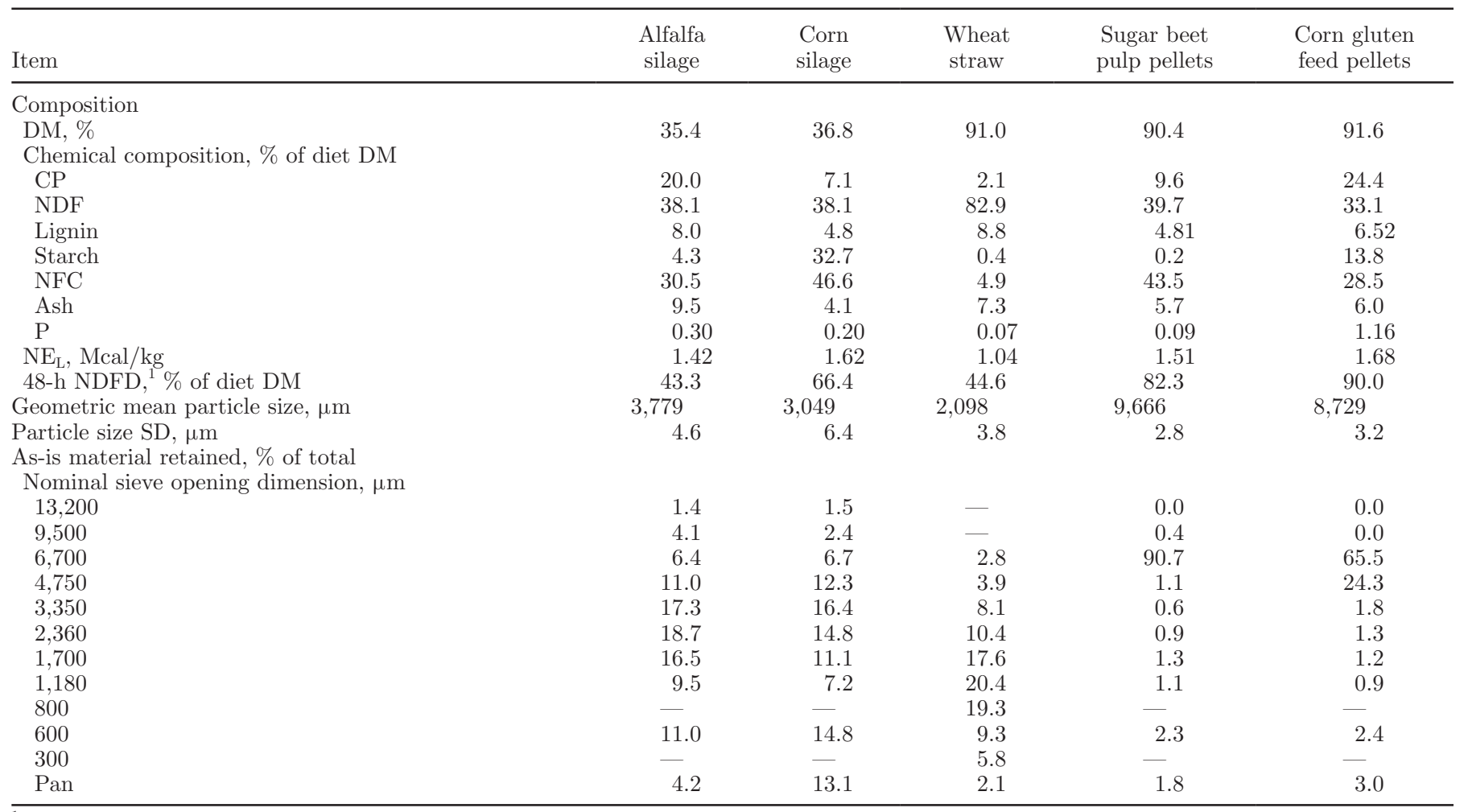

${ }^{1} \mathrm{NDFD}=\mathrm{NDF}$ digestibility. 
HALL AND CHASE

Table 3. Daily lactation performance and efficiency on covariate and experimental diets

\begin{tabular}{|c|c|c|c|c|c|c|c|c|}
\hline \multirow[b]{2}{*}{ Measure } & \multirow[b]{2}{*}{$\mathrm{Cov}^{1}$} & \multicolumn{4}{|c|}{$\mathrm{WS} / \mathrm{SBP}^{2}, \%$ of diet DM } & \multirow[b]{2}{*}{$\mathrm{SED}^{3}$} & \multicolumn{2}{|c|}{$P$-value ${ }^{4}$} \\
\hline & & $0 / 12$ & $3 / 9$ & $6 / 6$ & $9 / 3$ & & $\mathrm{~L}$ & $\mathrm{Q}$ \\
\hline DMI, kg & 22.0 & 26.9 & 25.9 & 25.9 & 25.4 & 0.62 & 0.03 & 0.51 \\
\hline DMI, $\%$ of BW & 3.42 & 4.01 & 3.85 & 3.90 & 3.83 & 0.09 & 0.09 & 0.53 \\
\hline Milk, kg & 32.7 & 32.2 & 32.8 & 31.2 & 30.9 & 0.95 & 0.08 & 0.54 \\
\hline Fat, $\%$ & 4.18 & 4.26 & 4.17 & 4.19 & 4.53 & 0.16 & 0.11 & 0.06 \\
\hline Protein, \% & 3.17 & 3.31 & 3.27 & 3.28 & 3.27 & 0.05 & 0.56 & 0.62 \\
\hline Lactose, $\%$ & 4.96 & 4.90 & 4.93 & 4.83 & 4.86 & 0.04 & 0.10 & 0.97 \\
\hline SNF, $\%$ & 9.01 & 9.09 & 9.10 & 9.03 & 9.04 & 0.06 & 0.28 & 0.96 \\
\hline $3.5 \% \mathrm{FPCM}^{5},^{5} \mathrm{~kg}$ & 35.3 & 36.3 & 36.0 & 35.3 & 35.3 & 1.65 & 0.48 & 0.92 \\
\hline MUN, mg/dL & 10.6 & 10.0 & 10.9 & 10.6 & 12.1 & 0.47 & $<0.01$ & 0.36 \\
\hline Fat, kg & 1.36 & 1.38 & 1.38 & 1.31 & 1.37 & 0.06 & 0.65 & 0.51 \\
\hline Protein, $\mathrm{kg}$ & 1.03 & 1.06 & 1.07 & 1.03 & 0.99 & 0.04 & 0.03 & 0.33 \\
\hline Lactose, kg & 1.63 & 3.51 & 3.60 & 3.39 & 3.25 & 0.14 & 0.03 & 0.25 \\
\hline $\mathrm{SNF}, \mathrm{kg}$ & 2.95 & 2.95 & 3.00 & 2.86 & 2.74 & 0.11 & 0.04 & 0.27 \\
\hline $3.5 \% \mathrm{FPCM} / \mathrm{DMI}$ & 1.61 & 1.36 & 1.41 & 1.36 & 1.38 & 0.063 & 0.98 & 0.71 \\
\hline Milk N/intake N & 0.28 & 0.23 & 0.25 & 0.24 & 0.24 & 0.009 & 0.93 & 0.15 \\
\hline BW change, $\mathrm{kg}$ & - & 31.9 & 26.5 & 25.3 & 24.9 & 6.14 & 0.26 & 0.56 \\
\hline
\end{tabular}

${ }^{1}$ Covariate period arithmetic mean values.

${ }^{2} \mathrm{WS}=$ chopped wheat straw; SBP $=$ sugar beet pulp pellets. Values for experimental diets are LSM.

${ }^{3}$ Standard error of the difference for experimental diets.

${ }^{4}$ Effects of experimental diets: $\mathrm{L}=$ linear; $\mathrm{Q}=$ quadratic.

${ }^{5} \mathrm{FPCM}=$ fat- and protein-corrected milk.

matter intake declined linearly with increasing WS and decreasing $\operatorname{SBP}(P=0.03)$ for a difference of $1.4 \mathrm{~kg}$ between greatest and lowest WS inclusion (Table 3 ). A tendency for a similar response was seen for DMI as a percentage of $\mathrm{BW}(P=0.09)$. Intake has been reported to decline as forage level was increased in diets of lactating cows (Schuler et al., 2013). The responses to forage or WS can be due to limitations of rumen fill as feeds with larger particles and relatively lower or slower fermentability than other feed components are added to diets (Conrad, 1966). On diets that are high in bulk (fill) and low in energy concentration, physical fill of the rumen can limit intake. Intake is negatively correlated with dietary NDF concentration when NDF concentration is altered primarily by bulky feeds such as forages (Mertens, 1994). Additionally, the filling effect of a diet is dependent on factors such as rate of digestion and particle size that affect digestion in and flow from the rumen (Allen, 2000), both of which remove mass from the rumen and reduce fill. In the present study, WS had approximately twice the NDF content and half the in vitro NDF digestibility of SBP. This suggests that, given equivalent particle sizes, WS would have a greater fill effect than SBP, which could lead to the decreased DMI noted as WS increased. The effect of differences in particle size between SBP and WS as related to fill and effect on DMI is more difficult to address. As previously noted, the large particle size measured for SBP likely does not accurately represent the particles contributed by SBP as the pellets disaggregate into their smaller constituent particles in the rumen. Additionally, long particles can pass through sieves if their cross-sectional diameter allows it. Thus, the particle size determined for the long, thin stems in WS does not necessarily account for their length. A 3-dimensional scheme for describing particle size of disaggregated feeds would improve characterization of fill contributions of individual feeds compared with the current sieving system. A casual observation made during ruminal sampling just before feeding was that the rumens of animals offered the $9 \% \mathrm{WS}+3 \%$ SBP diet were relatively more full of digesta than those of cows provided with $0 \% \mathrm{WS}+12 \% \mathrm{SBP}$.

Intakes of $\mathrm{CP}, \mathrm{NFC}$, starch, $\mathrm{NE}_{\mathrm{L}}$, and $\mathrm{P}$ all declined linearly and that of NDF increased linearly with increasing WS $(P<0.04$ for all; Table 4$)$. As calculated with the NRC (2001) diet evaluation model, the P consumed in the experimental diets provided more than twice the required amount of absorbable $\mathrm{P}$ (data not shown). The average daily intake of total $\mathrm{P}$ during the covariate period was $79 \mathrm{~g}(\mathrm{SD}=7.7)$, and $141 \mathrm{~g}(\mathrm{SD}=$ 14.5) in the experimental period.

Both milk yield and composition were altered by forage substitute treatments, likely in response to energy supply from the diets. Milk production and lactose percentage tended to decrease linearly with greater WS inclusion $(P \leq 0.10)$, whereas fat percentage tended to change quadratically, declining and then increasing $(P$ $=0.06)$. The declines in protein and SNF percentages, and amount of $3.5 \%$ FPCM were not affected by dietary treatments $(P>0.27)$. Although diet had no effect on fat yield $(P>0.50)$, protein, lactose, and SNF yields 
Table 4. Intake of feed fractions on experimental diets

\begin{tabular}{|c|c|c|c|c|c|c|c|c|}
\hline \multirow[b]{2}{*}{ Intake/d } & \multirow[b]{2}{*}{$\mathrm{Cov}^{1}$} & \multicolumn{4}{|c|}{$\mathrm{WS} / \mathrm{SBP},{ }^{2} \%$ of diet DM } & \multirow[b]{2}{*}{$\mathrm{SED}^{3}$} & \multicolumn{2}{|c|}{$P$-value ${ }^{4}$} \\
\hline & & $0 / 12$ & $3 / 9$ & $6 / 6$ & $9 / 3$ & & $\mathrm{~L}$ & $\mathrm{Q}$ \\
\hline $\mathrm{CP}, \mathrm{kg}$ & 3.65 & 4.53 & 4.30 & 4.22 & 4.10 & 0.10 & $<0.01$ & 0.48 \\
\hline $\mathrm{NFC}, \mathrm{kg}$ & 9.33 & 9.43 & 8.75 & 8.47 & 8.02 & 0.21 & $<0.01$ & 0.44 \\
\hline Starch, kg & 5.46 & 3.06 & 2.92 & 2.93 & 2.87 & 0.07 & 0.03 & 0.50 \\
\hline $\mathrm{NDF}, \mathrm{kg}$ & 6.34 & 8.84 & 8.82 & 9.18 & 9.33 & 0.21 & 0.01 & 0.58 \\
\hline $\mathrm{NE}_{\mathrm{L}}$, Mcal & 37.4 & 44.2 & 41.9 & 41.7 & 40.5 & 1.0 & $<0.01$ & 0.48 \\
\hline $\mathrm{P}, \mathrm{g}$ & 79 & 146 & 140 & 140 & 137 & 3.3 & 0.03 & 0.50 \\
\hline
\end{tabular}

${ }^{1}$ Covariate period arithmetic mean values.

${ }^{2} \mathrm{WS}=$ chopped wheat straw; SBP = sugar beet pulp pellets. Values for experimental diets are LSM.

${ }^{3}$ Standard error of the difference for experimental diets.

${ }^{4}$ Effects of experimental diets: $\mathrm{L}=$ linear; $\mathrm{Q}=$ quadratic.

all declined linearly with increasing WS and decreasing SBP $(P \leq 0.04)$. Milk urea nitrogen concentration increased linearly with increasing WS percentage $(P$ $<0.01$ ); however, the greatest numeric increase was between 6 and $9 \%$ WS. Increasing MUN concentration suggests decreasing energy availability to ruminal microbes to capture NPN as microbial protein or to the entire system, or to both, resulting in increased catabolism of absorbed protein. The decreases in milk and nonfat component yields follow the declines in DMI and calculated energy concentrations in the diets as WS inclusion increased. These responses suggest that limitations in energy availability from the diets and reductions in intake, whether due to rumen fill or other factors, limited lactation performance as more WS replaced SBP. The marked numeric increase in both fat percentage and MUN concentration on the $9 \%$ WS $+3 \%$ SBP diet raises the possibility that the animals were mobilizing body tissue to a degree that animals on other treatments were not, especially considering the lower $\mathrm{CP}, \mathrm{NFC}$, starch, and calculated $\mathrm{NE}_{\mathrm{L}}$ intakes for animals on that diet. However, a longer-term feeding study that includes measurements to detect tissue mobilization is needed to verify the basis for animal responses. Feed efficiencies for $3.5 \% \mathrm{FPCM}(P>$ $0.70)$ and nitrogen utilization $(P>0.14)$ were unaffected by treatment. Cows consuming the experimental diets had numerically greater DMI at approximately the same production level as in the covariate period. Consequently, both evaluations of feed efficiency were numerically lower on the experimental diets than in the covariate period.

The increases in BW measured on the experimental diets were not expected. Body weights increased by more than $24 \mathrm{~kg}$ for cows on all diets over the 4 -wk study and did not differ by treatment $(P>0.25$; Table 3 ). Numerically, a decrease in weight gain was observed from the $0 \% \mathrm{WS}+12 \% \mathrm{SBP}(31.9-\mathrm{kg}$ gain) to the $9 \%$ $\mathrm{WS}+3 \%$ SBP (24.9-kg gain) diet. The weight gain was not likely due to pregnancy; at the end of the study, average days pregnant were $109 \mathrm{~d}$, with a maximum of 200 d, calculated exclusive of 10 nonpregnant cows. Body condition was not monitored in this study. The changes in BW could be due to changes in body condition or to increased gut fill. The average DMI in the covariate period was $22.0 \mathrm{~kg}$, compared with $26.0 \mathrm{~kg}$ for all cows on the experimental diets. Unless rate of passage or digestibility increased to balance the numerically greater intake, it is possible that gut fill including water associated with the digesta would increase. With the lower predicted energy contents of the experimental diets compared with the covariate diet, it is not likely that diet digestibility was increased. The numerically increased DMI on the experimental diets relative to the covariate diet may have been related to attempts by the cows to meet energy requirements through increased intake (Conrad, 1966).

\section{Nutritional Model Predictions}

The nutritional models tested were not developed with low-forage, high-by-product diets predominating in their data sets, because few such studies are available. Typically, models are most accurate when they are used to predict performance on diets to which they are calibrated. For primiparous cows in the present study, predictions of milk production were affected by nutritional model $(P<0.01)$ and the quadratic effect of $\operatorname{diet}(P=0.03)$, but were not affected by effects of diet alone $(P=0.52)$, diet-by-model interaction $(P=0.34)$, or the interaction of model and the quadratic effect of $\operatorname{diet}(P=0.96$; Figure 3a). The least squares means for daily milk production of primiparous cows were 32.6 , $34.5,36.0,34.3$, and $29.8 \mathrm{~kg}$ for observed, ME- and MP-based CNCPS predictions, and $\mathrm{NE}_{\mathrm{L}^{-}}$and MPbased NRC predictions, respectively. Predictions based on MP in the NRC model underpredicted $(P=0.03)$ and in the CNCPS model overpredicted performance $(P=0.01)$. But, the energy-based predictions for both models did not differ from the observed (CNCPS: $P=$ 


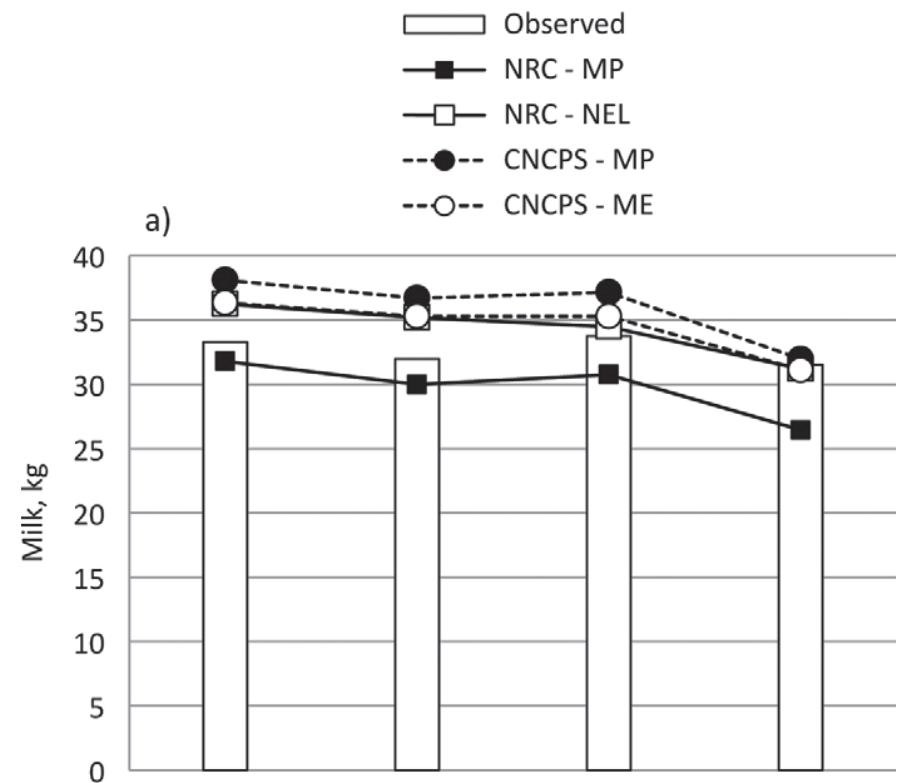

b)

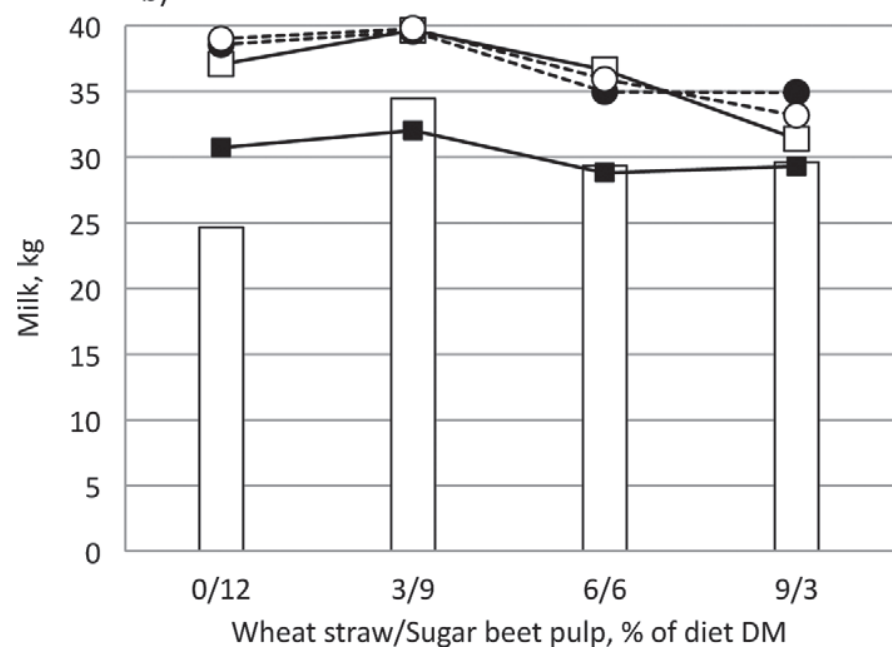

Figure 3. Performance predictions of the NRC (2001) and Cornell Net Carbohydrate and Protein System (CNCPS; Cornell University, Ithaca, NY) nutritional models compared with observed lactation performance. (a) Primiparous cows; (b) multiparous cows. Vertical bars represent observed performance. $\mathbf{\square}=\mathrm{NRC}$ predictions based on MP; $\square=$ NRC predictions based on $\mathrm{NE}_{\mathrm{L}} ; \bullet=$ CNCPS predictions based on MP; and $\mathrm{O}=$ CNCPS predictions based on ME.

0.21; NRC: $P=0.31$ ). The NRC MP-based predictions had smaller numeric differences from observed performance at the lower levels of WS inclusion, whereas NRC and CNCPS energy-based and CNCPS MP-based predictions showed smaller numeric differences as WS inclusion increased (Figure 3a).

Predictions of DMI for primiparous cows were affected by nutritional model $(P<0.01)$ and the quadratic effect of diet $(P=0.02)$, only tended to be affected by effects of diet alone $(P=0.08)$, and were unaffected by

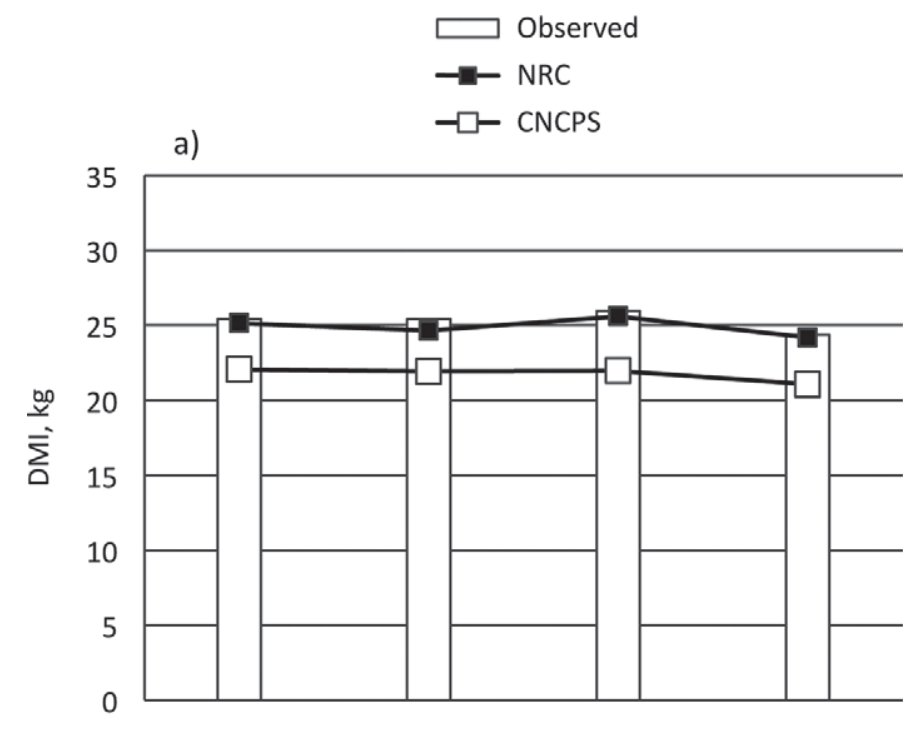

b)

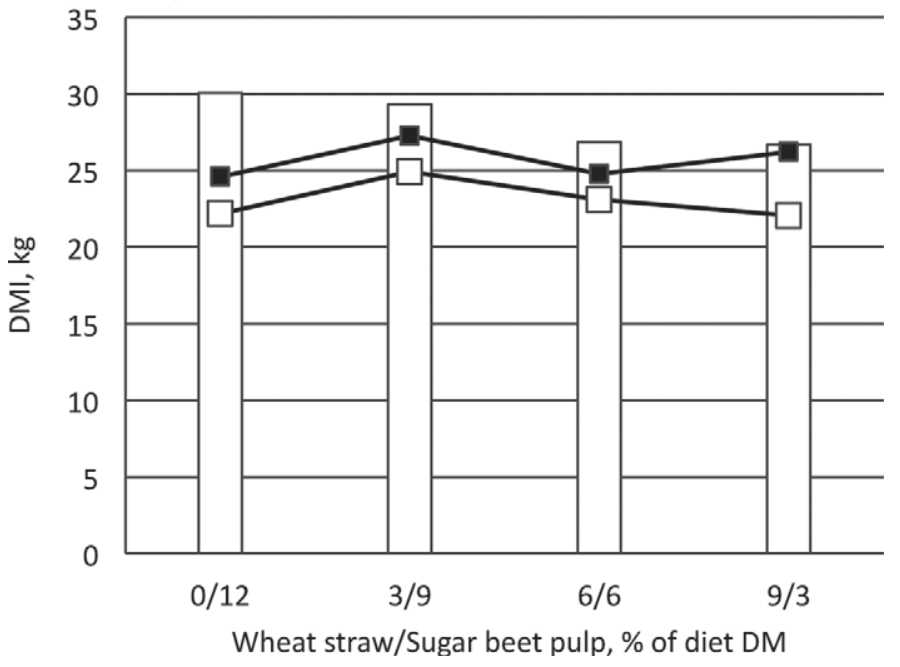

Figure 4. Dry matter intake predictions of the NRC (2001) and Cornell Net Carbohydrate and Protein System (CNCPS; Cornell University, Ithaca, NY) nutritional models compared with observed intakes. (a) Primiparous cows; (b) multiparous cows. Vertical bars represent observed DMI. $\mathbf{\square}=$ NRC predictions; $\square=$ CNCPS predictions.

the diet-by-model interaction $(P=0.93)$, or the interaction of model and the quadratic effect of $\operatorname{diet}(P=$ $0.73 ;$ Figure 4a). The NRC-predicted DMI $(24.9 \mathrm{~kg})$ did not differ from the observed DMI $(25.3 \mathrm{~kg} ; P=0.33)$, and the CNCPS prediction $(21.7 \mathrm{~kg})$ underestimated DMI by an average of $3.5 \mathrm{~kg}(P<0.01 ; \mathrm{SED}=0.28$ $\mathrm{kg})$.

For multiparous cows, predictions of milk production differed among models $(P<0.01)$, and the quadratic effect of diet tended to affect predictions $(P=0.06)$. No effects of diet alone $(P=0.20)$, of diet-by-model interaction $(P=0.27)$, and of interaction of model and the quadratic effect of $\operatorname{diet}(P=0.67)$ were detected 
(Figure 3b). The least squares means for daily milk production were $29.5,37.0,37.0,36.2$, and $30.2 \mathrm{~kg}$ for observed, ME- and MP-based CNCPS predictions, and $\mathrm{NE}_{\mathrm{L}^{-}}$and MP-based NRC predictions, respectively. Predictions based on ME and MP in CNCPS overpredicted performance $(P<0.01$ for both) as did prediction based on $\mathrm{NE}_{\mathrm{L}}$ from the NRC model $(P=0.02)$. Predictions based on MP in the NRC model did not differ from observed performance $(P=0.99)$. The numeric differences from actual performance for the energy-based and CNCPS MP-based predictions appeared to follow the same pattern as for the primiparous cows, declining as WS inclusion increased (Figure 3b). In contrast, with the exception of the $0 \% \mathrm{WS}+12 \%$ SBP diet, the NRC MP-based predictions for multiparous cows appeared to follow observed performance, with little numeric difference across the diets.

Predictions of DMI for multiparous cows were affected by nutritional model $(P<0.01)$ and tended to be affected by effects of the diet-by-model interaction alone $(P=0.06)$. Predictions were unaffected by effects of $\operatorname{diet}(P=0.13)$, quadratic effect of $\operatorname{diet}(P=0.40)$, or the interaction of model and the quadratic effect of $\operatorname{diet}(P=0.27$; Figure $4 \mathrm{~b})$. All model predictions and observed DMI differed from each other $(P<0.02$; SED $=0.68 \mathrm{~kg}$ ), with models underpredicting DMI. The DMI were $28.2,25.7$, and $23.1 \mathrm{~kg}$ for observed, NRC predicted, and CNCPS predicted, respectively. The NRC predictions appeared to converge with observed DMI as WS inclusion in the diets increased.

The curvilinear pattern of model predictions for milk production related to WS/SBP inclusion appeared to generally make model predictions converge with actual performance as WS inclusion increased. The exception to this was the NRC MP-based predictions, which appeared to diverge for the primiparous cows. The convergence may be due to the models being developed on data sets with diets that had greater amounts of forage and effective fiber and, thus, were better calibrated to predict performance on similar diets. The NRC MPbased predictions differed from other model predictions for the primiparous $(P<0.01$ for all comparisons $)$ and multiparous cows $(P<0.04$ for all comparisons). The reason for this is not certain. For both models, use of some library values within the programs (AA composition of feeds and fermentation rates) rather than use of analyzed values could have affected the model results. With the NRC model, it seems that predictions based on MP may be more accurate for multiparous cows, whereas the energy-based predictions of CNCPS or the NRC may be appropriate for primiparous animals. Although significant interactions of model and diet were not detected, the patterns of model predictions versus observed performance raises the question as to whether such differences were simply not detected. More data sets are needed to answer this question. The deviations between observed and predicted DMI emphasize the need to base diets on actual rather than predicted values when possible. Because of the importance of accurately predicting animal performance for making ration formulation decisions, the ability of models to predict such nontraditional diets needs to be further investigated and improved.

\section{Feed Costs and Milk Income}

Feed costs, milk income, and income over feed costs are reported in Table 5. With only 1 value for each diet, power to detect differences was likely limited. However, experimental diet costs $(P<0.01)$ and diet costs per cow per day $(P=0.02)$ declined linearly with increasing WS and declining SBP. This was related both to the declining DMI with increasing WS, and that WS was the most inexpensive purchased ingredient besides minerals in the diets. The tendency for a quadratic effect of diet on value of the milk produced per cow per day reflects an initial decline in milk value, with a nadir at $3 \% \mathrm{WS}+9 \% \mathrm{SBP}$ and then an increase through $9 \%$

Table 5. Feed costs and milk income for covariate and experimental diets

\begin{tabular}{|c|c|c|c|c|c|c|c|}
\hline \multirow[b]{2}{*}{ Item } & \multirow[b]{2}{*}{$\operatorname{Cov}^{1}$} & \multicolumn{4}{|c|}{$\mathrm{WS} / \mathrm{SBP},{ }^{2} \%$ of $\operatorname{diet} \mathrm{DM}$} & \multicolumn{2}{|c|}{$P$-value ${ }^{3}$} \\
\hline & & $0 / 12$ & $3 / 9$ & $6 / 6$ & $9 / 3$ & $\mathrm{~L}$ & $\mathrm{Q}$ \\
\hline Diet DM, $\$ / \mathrm{kg}$ & 0.321 & 0.318 & 0.312 & 0.305 & 0.299 & $<0.01^{4}$ & 1.00 \\
\hline Diet cost, $\$ /$ cow per day & 7.05 & 8.58 & 8.07 & 7.90 & 7.60 & $0.02^{4}$ & 0.52 \\
\hline Milk, $\$ / \mathrm{kg}$ & 0.430 & 0.432 & 0.425 & 0.426 & 0.441 & 0.10 & 0.08 \\
\hline Milk, $\$ /$ cow per day & 14.06 & 13.91 & 13.94 & 13.29 & 13.62 & $0.35^{4}$ & 0.76 \\
\hline Income/feed, $\$$ & 7.01 & 5.33 & 5.87 & 5.39 & 6.03 & $0.40^{4}$ & 0.94 \\
\hline
\end{tabular}


$\mathrm{WS}+3 \% \mathrm{SBP}(P=0.08)$. This response mirrors the tendency for a quadratic response in milk fat percentage, which also alters the value of the milk. Although neither milk income per cow per day nor income over feed costs was affected by treatment (for both, linear effect: $P=0.26$, quadratic effect: $P>0.75$ ), a numeric decline was observed in milk income and a numeric increase in income over feed costs with increasing WS inclusion. Although the diet with the greatest WS inclusion appears to be most profitable, concerns regarding adequacy of the diet in providing energy to meet cow requirements needs to be investigated before such diets are recommended. Numerically, the covariate diet had a greater cost per kilogram than the experimental diets. However, because of the numerically lower DMI, the covariate diet also had a numerically lower diet cost per cow per day and a greater income over feed cost. Because feed and milk prices can change substantially, selection of the most economically advantageous diet needs to be assessed using current prices.

\section{CONCLUSIONS}

Lactating dairy cows were able to maintain production on low-forage diets that included forage substitutes, and in which by-product feeds fully replaced corn grain and soybean products. Further work, including longer-term feeding studies, is needed to determine longer-term effects of such diets, including the effect on mobilization of BW. Model predictions of lactation performance appeared to improve with increasing WS and declining sugar beet pulp inclusion in the diets; models differed as to whether protein- or energy-based predictions provided the best fit to primiparous and multiparous cow performance. A rigorous evaluation and improvement in the accuracy of nutritional models to improve their prediction of animal performance on such nontraditional diets is needed to understand the biology and provide nutritionists with the tools needed to design diets that could enhance farm viability.

\section{ACKNOWLEDGMENTS}

We thank ADM Research (Decatur, IL) for their donation of the corn gluten feed used in this study, R. D. Shaver of the University of Wisconsin (Madison) for his input on the planning of this study, and J. W. Pitas of the USDA Agricultural Research Service (Madison, WI) for technical support.

\section{REFERENCES}

Adisseo. 2012. Upper Midwest milk price calculator. Accessed Oct. 4, 2012. http://www.adisseo.biz/milkpay/scenario/7.
Allen, M. S. 1997. Relationship between fermentation acid production in the rumen and the requirement for physically effective fiber. J. Dairy Sci. 80:1447-1462.

Allen, M. S. 2000. Effects of diet on short-term regulation of feed intake by lactating dairy cattle. J. Dairy Sci. 83:1598-1624.

ANSI/ASAE (American National Standards Institute/American Society of Agricultural Engineers). 1992. Method of determining and expressing particle size of chopped forage materials by screening. Standard S424.1, MAR1992 (R2007). Pages 663-665 in ASAE Standards. ASAE, St. Joseph, MI.

AOAC International. 1996. Official Methods of Analysis. 16th ed. AOAC International, Gaithersburg, MD.

Bailey, C. B., and C. C. Balch. 1961. Saliva secretion and its relation to feeding in cattle. 1. The composition and rate of secretion of parotid saliva in a small steer. Br. J. Nutr. 15:371-382.

Boguhn, J., H. Kluth, M. Bulang, T. Engelhard, and M. Rodehutscord. 2010. Effects of pressed beet pulp silage inclusion in maize-based rations on performance of high-yielding dairy cows and parameters of rumen fermentation. Animal 4:30-39.

Clark, P. W. and L. E. Armentano. 1997. Replacement of alfalfa neutral detergent fiber with a combination of nonforage fiber sources. J. Dairy Sci. 80:675-680.

Conrad, H. R. 1966. Symposium on factors influencing the voluntary intake of herbage by ruminants: Physiological and physical factors limiting feed intake. J. Anim. Sci. 25:227-235.

Goering, H. K., and P. J. Van Soest. 1970. Forage fiber analysis (Apparatus, Reagents, Procedures, and Some Applications). Agricultural Handbook No. 379. USDA Agricultural Research Service, Washington, DC

Hall, M. B. 2009. Determination of starch, including maltooligosaccharides, in animal feeds: Comparison of methods and a method recommended for AOAC collaborative study. J. AOAC Int. 92:42-49.

Hall, M. B., C. C. Larson, and C. J. Wilcox. 2010. Carbohydrate source and protein degradability alter lactation, ruminal, and blood measures. J. Dairy Sci. 93:311-322.

Hall, M. B., and D. R. Mertens. 2008. In vitro fermentation vessel type and method alter fiber digestibility estimates. J. Dairy Sci. 91:301-307.

Krause, K. M., D. K. Combs, and K. A. Beauchemin. 2002. Effects of forage particle size and grain fermentability in midlactation cows. II. Ruminal pH and chewing activity. J. Dairy Sci. 85:1947-1957.

Mertens, D. R. 1994. Regulation of forage intake. Pages 450- 493 in Forage Quality, Evaluation, and Utilization, G. C. Fahey Jr., M. Collins, D. R. Mertens, and L. E. Moser, ed., American Society of Agronomy, Crop Science Society of America, and Soil Science Society of America, Madison, WI.

Mertens, D. R. 2002. Gravimetric determination of amylase-treated neutral detergent fiber in feeds with refluxing in beakers or crucibles: Collaborative study. J. AOAC Int. 85:1217-1240.

Mooney, C. S., and M. S. Allen. 1997. Physical effectiveness of the neutral detergent fiber of whole linted cottonseed relative to that of alfalfa silage at two lengths of cut. J. Dairy Sci. 80:2052-2061.

NRC. 2001. Nutrient Requirements of Dairy Cattle. 7th rev. ed. Natl. Acad. Sci., Washington, DC.

Pereira, M. N., E. F. Garrett, G. R. Oetzel, and L. E. Armentano. 1999. Partial replacement of forage with nonforage fiber sources in lactating cow diets. I. Performance and health. J. Dairy Sci. $82: 2716-2730$.

SAS Institute. 2010. The SAS System for Windows. Version 9.3. SAS Institute Inc., Cary, NC.

Schuler, A. M., K. F. Kalscheur, D. P. Casper, and J. L. Anderson. 2013. Determination of the optimum dietary forage concentration when using canola meal as a primary protein source in lactating dairy cow diets. J. Dairy Sci. 96(E-Suppl. 1):397. (Abstr.)

Tyrrell, H. F., and J. T. Reid. 1965. Prediction of the energy value of cow's milk. J. Dairy Sci. 48:1215-1223.

USDA. 2013a. Crop production 2012 summary (January 2013). National Agricultural Statistics Service, Washington, DC.

USDA. 2013b. Feed grains data: Yearbook tables. Economic Research Service, Washington, DC. 